\title{
Subject Headings in Full-Text Environments: The ECCO Experiment
}

\section{Jeffrey Garrett}

\begin{abstract}
Bibliographic records regularly combine two incommensurable types of description: one that captures the physical and textual facts of a work, the other that seeks to encompass succinctly the work's intellectual content. This article deals with the second type of bibliographic description: subject headings and their contribution to resource discovery. The article reports on an experiment at Northwestern University Library to add subject headings to online records for the Eighteenth Century Collections Online (ECCO). The author assesses the benefits of this enhancement by using a representative research topic: a search for contemporary material on the East India Company (1600-1873). This article extends arguments recently presented by Gross and Taylor (2005) in two directions: first, by considering the importance of subject headings for access to historical materials; and, second, by examining the value added by subject headings even when the full text of a work is available online.
\end{abstract}

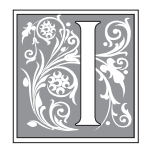

$f$ the focus of bibliographic description is the artifact - the precise capture of its physical and textual facts - the focus of subject headings work is the library user and his or her content-related needs and expectations. ${ }^{1}$ Ideally, subject headings enable users not familiar with the literature of a field to identify and gather together relevant works, regardless of their authors, titles, disparate physical locations, and what other major topics they may treat. In light of this focus on user needs, subject heading assignment is pragmatic and heuristic rather than an exercise in truth and accuracy. Subject headings can indeed be simply wrong, ${ }^{2}$ but normally the question to be asked is whether they are good or bad, helpful or irrelevant, rather than true (accurate) or false (incorrect). The assignment of subject headings cannot and need not conform to the same standards that apply to descriptive bibliography in the tradition of W. W. Greg and Fredson Bowers. ${ }^{3}$

What descriptive accuracy is to cataloging and bibliography, consistency is to the assignment of subject headings. The use of carefully controlled vocabulary consistently applied and combined allows the creation of mechanical linkages between records, forming the basis for subject catalogs in both paper and electronic form. In this way, subject headings create mul-

Jeffrey Garrett is Assistant University Librarian for Collection Management at Northwestern University Library; e-mail:jgarrett@northwestern.edu. This paper originated as a presentation to the International Committee for the English Short Title Catalogue (IESTC) at their meeting on September 12, 2005, hosted by the American Antiquarian Society in Worcester, Massachusetts. The author especially thanks Gary L. Strawn, Authorities Librarian at Northwestern University Library, for his many contributions to this article. 
tidimensional networks between works, complexities of relationship going far beyond the classificatory power of linear arrangements of books on shelves. These complex, multidimensional relationships ideally mirror in the aggregate what in 1945 Vannevar Bush called the "associative trails" between separate sources of information that human memory creates over a lifetime of learning and reading. ${ }^{4}$ Consistency requires further that controlled vocabulary be constantly updated and improved, since classificatory words and concepts - unlike the physical facts of a publication-change over time and gain or lose acceptance. Maintenance of useful subject catalogs and thesauri was a daunting if not impossible task in a precomputer environment, but is perhaps more within our grasp today.

Subject access to materials published in Great Britain between 1701 and 1800 has always posed a particular problem for scholars and students. While the English Short Title Catalogue (ESTC) contains Library of Congress Subject Headings (hereafter: LCSH) for books from the English-speaking world printed before 1701, entries for material dating from 1701 to 1800 are not subject indexed. The British Library and other major research libraries have historically acknowledged this problem, directing onsite users to Averley's encyclopedic four-volume Eighteenth-Century British Books ${ }^{5}$ or to the myriad print subject bibliographies that exist on topics both prominent and arcane, from English Maritime Books Printed before 1801 to English Cookery Books to the Year 1850. ${ }^{6}$ Users of the British Library's online Integrated Catalogue, which derives its eighteenthcentury records from the ESTC and therefore lacks subject headings for works published in that century, are directed to scour book titles for subject information. Users "should find early books with a title (or series title) which encapsulates the work's subject matter," presumably through keyword searches in the title field. Yet there are problems, since: "Such a search will inevitably find a fair number of irrelevant items." ${ }^{7}$ A far greater problem with the suggested search strategy than the generated bibliographic noise, however, is that title keyword searches miss an enormous amount of relevant material, since words we might use to describe a historical topic today are often entirely different from words populating actual eighteenth-century book titles. For a number of reasons, some having to do with changes in the lexicon, some with a century-specific perceived need for circumlocution, words such as "hygiene" and "prostitution" occurred far less frequently in the eighteenth century than they do today - not to mention the often disastrous effects of pre-1800 orthography on modern-day keyword searches. ${ }^{8}$

An already difficult situation has been aggravated recently by the sudden (and otherwise hugely welcome) availability of a new and mammoth library of searchable eighteenth-century text online through Thomson Gale's Eighteenth Century Collections Online (ECCO). ${ }^{9}$ This new resource has meant that tens and even hundreds of thousands of students and nonspecialist faculty at over a hundred universities across the world, from Germany, Great Britain, and the United States to Japan and Hong Kong, now have convenient full-text access to 150,000 eighteenth-century monographs with 26,000,000 pages of content. Bibliographic access has already been significantly enhanced by loading MARC records derived from the ESTC (i.e., without subject headings) into online catalogs, allowing users to easily locate known items, but also to encounter titles that appear relevant to their needs when search terms happen to match up with eighteenth-century title words. In effect, the British eighteenth century, which includes most of the American eighteenth century as well, has been transformed for the nonspecialist user from a bibliographic terra incognita to what is almost literally an open book. In theory at least, students of the history of slavery, of the Age of Exploration, of disease and sanita- 
tion in both British and American cities, or of our own War of Independence now have direct access to the primary texts in which these topics were discussed and debated.

But can our user communities take advantage of this enormous amount of material and truly find eighteenth-century texts appropriate to their needs?

\section{Adding Subject Headings to ECCO}

In the summer of 2005, an experiment was conducted on a representative sample of bibliographic material contained in the OPAC of Northwestern University Library to help determine the benefits of adding subject headings to bibliographic records for pre-1800 monographs. Before describing this experiment, some background is necessary. Northwestern, like many other large research libraries, has acquired both Chadwyck-Healey's Early English Books Online (EEBO $)^{10}$ and ECCO, containing close to 125,000 and 150,000 monographs, respectively. Both of these huge collections were acquired with MARC records sets, the former including $\mathrm{LCSH}$, the latter, ECCO, almost completely without. In an effort to increase use of ECCO by its community and to realize to the fullest possible extent the benefit of this quarter-million-dollar investment, Northwestern harvested records from WorldCat containing subject headings for eighteenth-century titles in ECCO. ${ }^{11}$ In the harvest corpus of approximately 52,000 records, a total of 30,948 different subject headings were applied 107,477 times - an average of slightly more than two subject headings per title. The subject headings thus harvested were then mapped onto ECCO records in Northwestern's catalog (NUcat), leaving all other descriptive data untouched. About 80,000 ECCO records (of the total 132,000 searched) were left at the end of this project without subject headings $(60.1 \%)$. The harvesting and mapping operations were planned and carried out in June 2005 by Gary Strawn, Authorities Librarian at Northwestern University Library.
An examination of the 30,000-plus individual subject headings retrieved and mapped yielded a highly interesting distribution. (See Appendix.) The most frequently occurring LCSH were for genres of religious literature (e.g., sermons, hymns, works on "Christian life"). The heading "Sermons-English-18th Century," for example, was assigned 1776 times. The other subject headings cover-no surprise-a very broad range; for example:

Walpole, Robert, Earl of Orford-
1676-1745 (149 times)
Seven Years War-1756-1763
(113 times)
Astronomy - Early works to 1800
(89 times)
Soul (51 times)
Tobacco Industry - Great Britain
(6 times)
Slave Trade-Great Britain-
Colonies (5 times)

Actual corpus numbers for these subjects are usually quite a bit higher, of course, which we discover if relevant LCSH are grouped not by frequency, but alphabetically. We find, for example, that not one, but sixteen subject headings are devoted to Robert Walpole, the early eighteenth-century British prime minister, yielding a total of 194 occurrences -45 more than the main heading alone. ${ }^{12}$ By locating keyword occurrences within subject headings, retrieval numbers go even higher: "Slavery" or "Slave Trade," for example, are not always the initial words in assigned subject headings in which they occur (e.g., "Society of Friends-Slavery"). ${ }^{13}$ This, of course, offers yet another reason why keyword searching across the entire bibliographic record is so important. It is supported by virtually all modern OPACs and vastly enhances the usefulness of subject headings beyond that of the stolidly alphabetized traditional subject catalog in paper form. ${ }^{14}$

The extent and quality of the harvested subject headings vary markedly. This 
should also come as no surprise, since the records come from numerous different institutions and have been created over a span of many decades. There are, for example, occasional misspellings (e.g., one occurrence each of "Aantomy-Early works to 1800" and "Yokrtown (Va.) History-Siege, 1781"). Additionally, we find various naïve mistakes (e.g., a subject heading identifying a certain "John Prester" - while the valid subject heading should read "Prester John [Legendary character]"). Far more frequently, we encounter vague and therefore virtually meaningless subject headings (e.g., "Great Britain-Politics and Government": 155 occurrences). Others, meaningless perhaps in a print or card catalog environment (e.g., "Biography": 17 occurrences), take on new significance and utility when used in Boolean searches.

Inconsistencies in subject heading assignment are, as is well known, rampant-but given new search methodologies in an online environment, they may not really be all that critical. Here, too, it helps that users today find what they are looking for by using subject headings not as verbatim search expressions, but as sources for frequently unique keyword material. Boolean searches across subject headings, combining, say, "bengal" with "east india company," represent discovery possibilities that are extraordinarily quick and efficient to execute online, very difficult to replicate in card catalogs and far more precise (i.e., likely to be successful) than searches using only title page information.

By contrast to the many cases where too few or too general subject headings have been created for individual works, we also record, gratefully, frequent examples of the opposite, where rich and diverse subject headings expose an otherwise invisible work to discovery from numerous different angles. Take, for example, one of the more detailed records acquired through the ECCO WorldCat harvesting operation, for a work entitled An authentic account of the proceedings of their High Mightinesses, the states of Holland and West-Friezeland, on the complaint laid before them by His Excellency Sir Joseph Yorke, His Britannic Majesty's Ambassador at the Hague .. . (1762), for which the following subject headings were harvested from WorldCat and mapped onto the existing ECCO record:
East India Company - Political activity-Early works to 1800. 1
Nederlandsche Oost-Indische
Compagnie-Political activity-Early works to 1800. 1
Anglo-French War, 1755-1763- 1
Influence-Early works to 1800. 1
India-Commerce-Europe-Early
works to 1800.1
Europe-Commerce-India-Early
works to 1800.1
Bengal (India) - History - 18th
century. 1
Netherlands-Relations-Great
Britain-Early works to 1800. 1
Great Britain-Relations - 1
Netherlands-Early works to 1800. 1

Against this background we can ask: Will the addition of this considerable mass of subject heading material significantly improve user access to ECCO and, in this way, access to eighteenth-century materials more generally? And: What would be the hoped-for benefit of continuing this harvesting operation?

\section{Adequacy and Impact of the New ECCO Subject Headings}

To make a preliminary determination of the value of the subject heading harvesting and mapping operation, we decided to conduct an initial demonstration study on a single, representative research topic. The topic we chose was the one just encountered, namely the British East India Company. ${ }^{15}$ The selection of the East India Company made sense as it was a corporate entity that existed for much of the early modern period, beginning in 1600 , and is still referred to by the same name today - which allowed us to set aside 
questions of lexical or semantic change. There were many other possible topics (e.g., witchcraft, slavery, urban sanitation, and any number of prominent and less prominent historical, literary, and legendary persons), all of which have in common that they figure as research topics chosen by members of a typical academic community. We felt that if the results of the present study appeared promising, a more extensive sample could show the impact of LCSH record enhancement for study across the spectrum of student and faculty research.

The sample upon which the experiment was based was taken by Northwestern library staff on August 31, 2005, and the results reported here reflect the contents of the OPAC on that date. ${ }^{16}$ Here were the instructions:

- Search Northwestern's OPAC, NUcat, to find as many relevant pre-1800 monographs as possible touching on the history of the East India Company. ${ }^{17}$

- Focus on the discovery of electronically available materials in Early English Books Online and Eighteenth Century Collections Online.

- Attempt to determine how much material is now discoverable through the addition of subject headings to 52,000 ECCO records-but also seek to quantify how much has been left undiscovered by the absence of a complete subject headings file for ECCO.

- Throughout, use a search methodology typical of normal use by normal users (i.e., without consulting print bibliographies, reference librarians, or subject specialists). Also, as everyone knows, normal users do not perform subject searches, so these were not used here. ${ }^{18}$

Here are the results of the study:

In Northwestern's online catalog NUcat, the keyword phrase "east india company" occurred in 1,101 records overall. Of these records, 787 were for pre- 1800 imprints. Of these 787, 699 (89\%) were available electronically - testimony to the enormous impact that acquisitions such as EEBO and ECCO have had on early modern resources that libraries can now make available to their communities.

Of the stated 699 records for electronically available items containing the keyword phrase "east india company," $430(61.5 \%)$ had the phrase "east india company" in the subject headings field, while 269 did not. Of the 430 that did, 134 $(31.2 \%)$ were in EEBO, 296 (68.8\%) were in ECCO, the latter, of course, all being subject headings added from WorldCat records in the harvesting operation described above. Of the 269 that did not have "east india company" in the subject headings, but instead somewhere else in the record, $28(10.4 \%)$ were in EEBO, ${ }^{19}$ while the great majority, $245(91.1 \%)$, were-not surprisingly - in ECCO. ${ }^{20}$

Now, how many of the 430 records with "east india company" in the subject headings field would have been discovered by the keyword phrase search "east india company" without the subject headings? Or phrased another way: how many of these 430 records had "east india company" both in the subject headings and somewhere else in the record? There was no boolean search capable of providing a satisfactory answer to this question. Therefore, two random samples ${ }^{21}$ of 50 records each were prepared from the larger EEBO and ECCO retrieval sets (134 and 296 records, respectively), with the following results:

- In EEBO, 31 of the 50 sample records $(62 \%)$ had "east india company" in the subject headings field but nowhere else in the record. Some creative searching would have been necessary on the part of library users to turn up a number of alternative spellings in the actual bibliographic records, among these: East-Indie Companie - East-Indye Company - EastIndia Companies - East India Co. - East India House. But many searchers would simply not have found these records using a simple keyword phrase search. Most importantly, however: a clear majority of works identified by catalogers as pertaining significantly to the East India 
Company lack any direct reference to this corporate body in the record-other than in the subject field.

- In ECCO: 30 of 50 sample records $(60 \%)$ had "east india company" only in the subject headings field. Of the 20 that had the phrase elsewhere in the record as well, several occurrences (4) were in the Notes field (MARC 500) and one was in the Alternative Titles field (MARC 246) as a docket title.

To assess the number of works of possible relevance to this search that remain undiscovered in ECCO due to lack of subject access, it is necessary to project the results above into the corpus of electronically available material currently lacking subject headings in our catalog.

Recall that as of the date of this experiment, Northwestern had loaded 52,000 MARC records for ECCO titles enhanced with subject headings harvested from WorldCat, leaving 80,000 for which no subject headings had yet been harvested and mapped onto catalog records for ECCO titles. Many of these will, of course, be belletristic in nature (i.e., would not under policies in effect at the time of cataloging have had subject headings assigned). For this and other good reasons, it would be questionable to just extend the figures that apply to the 52,000 to the balance of the corpus.

A more promising but very speculative method would be to take the 245 ECCO records with "east india company" somewhere in the record but not in the subject heading as "the $40 \%$ " of records in the as-yet unharvested part of ECCO and add to them "the $60 \%$," or 367 estimated records with "east india company" in subject headings awaiting harvesting or creation.

These investigations (and speculations) yield the following final figures for Northwestern's library:

\section{Findings}

The WorldCat harvesting project added 177 titles to the 610 pre-1800 imprints having to do with the East India Company discoverable before the project. The new total is 787 , an increase of $29 \%$.

The 367 pre-1800 imprints having to do with the East India Company are estimated to be currently bibliographically undiscoverable in ECCO. As a result of further harvesting operations (for example, as might be possible from other library catalogs-and, at some point, through original cataloging of the remaining ESTC records), we could increase the total retrieval to 1,154 titles in our OPAC, a projected $89.2 \%$ increase vis-à-vis the status quo.

We can only guess at the significance of this vastly improved bibliographic transparency of eighteenth-century materials for students and for scholars.

It is interesting to compare the results reported here with those of a recent study by Tina Gross and Arlene G. Taylor presented in College \& Research Libraries, May 2005. Their study asked:

\section{... what proportion of records re- trieved by a keyword search has a keyword only in a subject heading field and thus would not be retrieved if there were no subject headings? It was found that more than one-third of records retrieved by successful keyword searches would be lost if subject headings were not present, and many individual cases exist in which 80, 90, and even 100 percent of the retrieved records would not be retrieved in the absence of subject headings. ${ }^{22}$}

The fact is that the assignment of descriptive language in the subject heading fields frequently attaches important terms and concepts to a bibliographic record that the record will not otherwise contain.

Once again, the "experiment" reported here should not be regarded as an exhaustive scientific study -in part because the author openly confesses to lacking the statistical skills necessary to conduct one. Further research is necessary, as will be 
described in a moment. Still, the study does appear to point to the potential improvements in discovery and access that the addition of subject headings to ECCO records have already brought at one university and would continue to bring if this work were continued. Inasmuch as ESTC records are also intended to improve access and facilitate discovery in addition to being a faithful reproduction of the bibliographic facts of publication, they, too, would benefit from this addition. ${ }^{23}$

\section{What About Keywords in Full-text?}

Let us take this discussion one step further by considering the role of subject headings in an environment in which users can also search the full text of an eighteenth-century work. In the article by Gross and Taylor already mentioned, this important question (i.e., the relevance of subject headings in an era of full-text searching) was not considered. Yet precisely this question is what is troubling administrators of large American libraries who must choose to fund classification work or not-among them, Deanna Marcum of the Library of Congress: "[I]n the age of digital information, of Internet access, of electronic key-word searching," she asks, "just how much do we need to continue to spend on carefully constructed catalogs?"24

In response, it can be readily shown that keyword searching in full-text databases is no substitute for searches run against OPACs or other bibliographic files with ample descriptors and subject headings. This observation applies a fortiori for historical text files such as ECCO. The demonstrable fact is that full-text searching of eighteenth-century texts often does not retrieve examples of terms that describe the work as a whole or even important topics or aspects of the work, especially as we might describe them today. Indeed, those researching the topic of urban sanitation in the eighteenth century might be surprised to learn that there is not a single valid occurrence of the word "sanitation" in the entire 26,000,000-page ECCO corpus.
Even the word "hygiene" occurs in the full text of only 50 ECCO titles - while just the subject headings already mapped to ECCO MARC records include the word "hygiene" in records for 60 ECCO titles. Northwestern's catalog NUcat, now "souped up" through the addition of the 52,000 imported records, currently retrieves 67 ECCO titles that include the word "hygiene" somewhere in the record (i.e., $34 \%$ more than a full-text search of the entire ECCO database would yield). Presumably, the further back in time we go, the greater the disjunction becomes between accurate descriptive terms and the words actually occurring in a workwhich is why the selection of "east india company" as a search string was, for the purposes of this study, such a benign one. With foreign-language works, of course, the disjunction approaches $100 \%$. Meta-vocabulary, therefore, performs an important hermeneutic and heuristic function in bibliographic searching and discovery, across centuries and across languages - and, as we have seen, even across states of the same language over time.

Future studies will need to explore the impact of subject headings for searches focusing not on proper names and corporate entities (such as the East India Company), but on more arcane phenomena (e.g., "beaver hats") and, above all, concepts used as subject headings (e.g., "conduct of life," "the sublime," "imaginary conversations"), since these may not map verbatim to eighteenth-century discourses and are also more susceptible than proper nouns and identifiers for material objects to go into and out of use in a matter of decades. Another direction for further research could be to investigate whether "smart" relevance-determining algorithms run against full text can produce distillations of content, replacing the need for manually assigned subject headings. These descriptions may not even be representable as LCSH-like verbal strings-and, in terms of aiding users, may not need to be. If, however, visible-readable subject headings are still felt to be necessary, 
couldn't they be derived and applied by these same automated text analysis procedures? The personal prejudice of this author, I confess, is that good subject headings, like good content analysis and text interpretation, will likely always remain a matter of "intelligent design" - the "intelligence" here being that which human agents bring to bear on interpreting the human record.

\section{Notes}

1. Kathryn Luther Henderson, "Subject Headings," in Encyclopedia of Library History, ed. Wayne A. Wiegand and Donald G. Davis, Jr. (New York \& London: Garland, 1994), 605.

2. Flat-out mistakes in the assignment of subject headings are unfortunately not uncommon - their consequences will be considered later in this article. For now, let one amusing example suffice, a children's book the author found once in a catalog entitled The Travels of Magnus Pole, about a fictional Viking bored with his life on the Shetland Islands who sets out in a dinghy for the Levant. Its one subject heading reads: "Polo, Marco, 1254-1323? -Juvenile literature."

3. Fredson Bowers, Principles of Bibliographical Description (Princeton, N.J.: Princeton University Press, 1949); W. W. Greg, Collected Papers, ed. J. C. Maxwell (Oxford: Clarendon Press, 1966).

4. Vannevar Bush, "As We May Think," Atlantic Monthly (July 1945): 106. Available online at http://www.ps.uni-sb.de/ duchier/pub/vbush/vbush-all.shtml.

5. G. Averley, Eighteenth-century British Books: A Subject Catalogue Extracted from the British Museum General Catalogue of Printed Books, 4 vols. (Folkestone: Dawson, 1979).

6. Thomas Randolph Adams and David Watkin Waters, English Maritime Books Printed Before 1801: Relating to Ships, Their Construction and their Operation at Sea; Including Articles in the Philosophical Transactions of the Royal Society and the Transactions of the American Philosophical Society (Providence, R.I.; Greenwich, England: John Carter Brown Library; National Maritime Museum, 1995); Arnold Whitaker Oxford, English Cookery Books to the Year 1850 (London; New York [etc.]: Oxford University Press; H. Frowde, 1913).

7. See The British Library's "Subject Access to Early Printed Materials in the British Library." Available online at http://www.bl.uk/collections/early/subject.html.

8. Cf. Jeffrey Garrett, "KWIC and Dirty? Human Cognition and the Claims of Full-Text Searching," Journal of Electronic Publishing 8, no. 1 (2006). Available online at http://hdl.handle. net/2027/spo.3336451.0009.106.

9. More information available online at http://www.gale.com/EighteenthCentury/.

10. For further information, see http://hdl.handle.net/2027/spo.3336451.0009.106.

11. As a rule, these were catalog records created for print versions of eighteenth-century monographs and contributed by OCLC member libraries. The actual harvesting work involved first dividing the 132,000 ECCO MARC records into files of about 10,000 records each. A macro written to run under OCLC's Passport program serially read the records in each of these files. For each record, the macro performed a single search in OCLC that combined author, title, and date criteria, skipping over any ECCO record with no main entry field. Records retrieved by this search were examined by the macro to make sure the titles corresponded. In a final macro step, the LCSH subject headings were copied bodily from the first such matching OCLC record into the corresponding ECCO record.

12. The subject heading "Walpole, Robert, Earl of Orford, 1676-1745-Poetry," for example, was assigned thirteen times.

13. The fact that "Society of Friends-Slavery" is not a valid LCSH string has not prevented it from being used. Thanks to Gary Strawn for this observation.

14. Of course, not even the most sophisticated OPACs currently support left truncation, meaning, at least for now, that "slavery" will be found by user-initiated keyword searches, but not "antislavery."

15. As historical background, the East India Company was incorporated by royal charter on December 31, 1600, and, after merging with a rival in 1708, was renamed the United Company of Merchants of England trading to the East Indies, or the United Company for short. It lost its trading monopolies beginning in the late 18th century and ceased to exist as a legal entity in 1873. (Source: Encyclopaedia Britannica.)

16. http://nucat.library.northwestern.edu/

17. To be as complete and as circumspect as possible, even with the addition of subject headings containing "East India Company," some information will be overlooked due to inconsistencies in heading assignment. Consider, for example, subject headings beginning with "East Indies..." 
(e.g., "East Indies - Commerce-Great Britain - Early Works to 1800”). The total number of occurrences of subject headings beginning with "East Indies..." is around 20 in the existing database of harvested ECCO records.

18. Interesting in this context and on the topic of subject headings as a whole: Thomas Mann, "Research at Risk," Library Journal 130, no. 12 (2005).

19. The search key used was ("early english books online")[in Keyword Anywhere] AND ("east india company")[in Keyword Anywhere] NOT ("east india company")[in Subject].

20. I have not yet been able to explain the minor discrepancy of four records $(28+245=273$, not 269), but I don't believe it invalidates the general thrust of this argument.

21. Titles retrieved were sorted in alphabetical order, yielding for the purposes of this investigation a fairly random sample.

22. Tina Gross and Arlene G. Taylor, "What Have We Got to Lose? The Effect of Controlled Vocabulary on Keyword Searching Results," College \& Research Libraries 66, no. 3 (2005): 212.

23. Shortly after completion of this manuscript, The British Library announced that it intended to add LCSH to all 18th-century records in the ESTC by autumn 2007. The subject headings extracted by Northwestern from the WorldCat database will constitute an important part of this enhancement project.

24. Deanna B. Marcum, "The Future of Cataloging: Address to the Ebsco Leadership Seminar," in ALA Midwinter Meeting (Boston, Mass.: 2005), 1.

\section{0,000 Publishing Sources. 3.2 Million Book Titles. We're Connected. Are You?}

IT'S EASY TO BE CONNECTED WHEN YOU'RE AN EMERY-PRATT CUSTOMER.

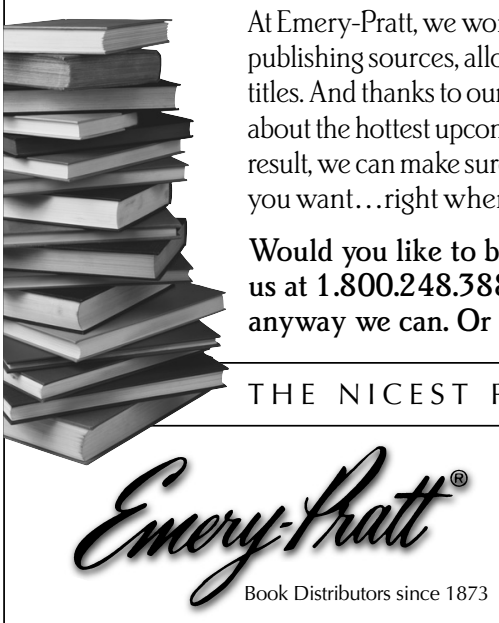

At Emery-Pratt, we work extra hard to be closely connected to more than 70,000 publishing sources, allowing you to have access to millions of new book titles. And thanks to our close relationship with these sources, we learn about the hottest upcoming books long before they're released. As a result, we can make sure you and your customer get all the books you want...right when you want them.

Would you like to be connected? It's easy. Just call us at 1.800.248.3887. We'd love to help you anyway we can. Or go online at emery-pratt.com

1966 West M-21, Owosso, MI 48867-1397 | Phone (toll-free) 1.800.248.3887 Fax (toll-free) 1.800.523.6379 | E-mail: mail@emery-pratt.com 


\begin{tabular}{|c|c|}
\hline & $\begin{array}{l}\text { APPENDIX } \\
\text { Selections from the Subject Headings List }\end{array}$ \\
\hline Groul & Most frequently assigned subject headings \\
\hline 1776 & SERMONS ENGLISH 18TH CENTURY \\
\hline 1201 & CHURCH OF ENGLAND SERMONS \\
\hline 915 & SERMONS ENGLISH \\
\hline 844 & ENGLISH DRAMA \\
\hline 504 & GREAT BRITAIN POLITICS AND GOVERNMENT 1760-1789 \\
\hline 461 & CHURCH OF ENGLAND SERMONS 18TH CENTURY \\
\hline 392 & UNITED STATES POLITICS AND GOVERNMENT 1775-1783 \\
\hline 380 & GREAT BRITAIN POLITICS AND GOVERNMENT 1727-1760 \\
\hline 367 & HYMNS ENGLISH \\
\hline 364 & FUNERAL SERMONS \\
\hline 350 & GREAT BRITAIN POLITICS AND GOVERNMENT 1702-1714 \\
\hline 296 & CHRISTIAN LIFE \\
\hline 293 & CONDUCT OF LIFE \\
\hline 290 & OPERAS LIBRETTOS \\
\hline 284 & GREAT BRITAIN POLITICS AND GOVERNMENT 1789-1820 \\
\hline 265 & DISSENTERS RELIGIOUS ENGLAND \\
\hline 253 & APOLOGETICS EARLY WORKS TO 1800 \\
\hline 232 & GREAT BRITAIN FOREIGN RELATIONS FRANCE \\
\hline 223 & SOUTH SEA COMPANY \\
\hline 211 & FRANCE FOREIGN RELATIONS GREAT BRITAIN \\
\hline 210 & FRANCE HISTORY REVOLUTION 1789-1799 \\
\hline 207 & SPANISH SUCCESSION WAR OF 1701-1714 \\
\hline 201 & IRELAND HISTORY THE UNION 1800 \\
\hline 200 & DEBTS PUBLIC GREAT BRITAIN \\
\hline Groul & I: A selection of relatively frequently applied subject headings \\
\hline 21 & ADULTERY \\
\hline 21 & ANGLICAN COMMUNION ENGLAND LITURGY TEXTS \\
\hline 21 & APOLOGETICS HISTORY 17TH CENTURY \\
\hline 21 & BEDFORD FRANCIS RUSSELL DUKE OF 1765-1802 \\
\hline 21 & BEES \\
\hline 21 & BRIEFS GREAT BRITAIN \\
\hline 21 & BURNET GILBERT 1643-1715 \\
\hline 21 & CALVINISM \\
\hline 21 & CHRISTIAN BIOGRAPHY \\
\hline 21 & CHURCH OF ENGLAND DOCTRINES EARLY WORKS TO 1800 \\
\hline
\end{tabular}


Subject Headings in Full-Text Environments: The ECCO Experiment 79

\begin{tabular}{|c|c|}
\hline & $\begin{array}{l}\text { APPENDIX } \\
\text { Selections from the Subject Headings List }\end{array}$ \\
\hline 21 & CHURCH OF ENGLAND FINANCE \\
\hline 21 & CLASSICAL BIOGRAPHY \\
\hline 21 & CONVERSION EARLY WORKS TO 1800 \\
\hline 21 & COURT RULES GREAT BRITAIN \\
\hline 21 & EDUCATION IRELAND \\
\hline 21 & ELECTIONS GREAT BRITAIN \\
\hline 21 & ELECTIONS IRELAND DUBLIN \\
\hline 21 & ENGLAND AND WALES CORPORATION ACT 1661 \\
\hline 21 & EUROPE POLITICS AND GOVERNMENT 1789-1815 \\
\hline 21 & FREDERICK II KING OF PRUSSIA 1712-1786 \\
\hline 21 & FRENCH LANGUAGE DICTIONARIES ENGLISH \\
\hline 21 & GREAT BRITAIN FOREIGN RELATIONS \\
\hline 21 & GREAT BRITAIN FOREIGN RELATIONS 1702-1714 \\
\hline 21 & GREAT BRITAIN FOREIGN RELATIONS TREATIES \\
\hline 21 & GREAT BRITAIN HISTORY COMIC SATIRICAL ETC \\
\hline 21 & IMAGINARY CONVERSATIONS \\
\hline 21 & JESUITS CONTROVERSIAL LITERATURE \\
\hline 21 & LOVE RELIGIOUS ASPECTS CHRISTIANITY \\
\hline 21 & MATHEMATICS \\
\hline 21 & NEWTON ISAAC SIR 1642-1727 PRINCIPIA \\
\hline 21 & NUMISMATICS GREAT BRITAIN \\
\hline 21 & ROCHEFORT EXPEDITION 1757 \\
\hline 21 & SERMONS ENGLISH SCOTLAND 18TH CENTURY \\
\hline 21 & SLAVE TRADE AFRICA \\
\hline 21 & $\begin{array}{l}\text { SOCIETY FOR PROMOTING CHRISTIAN KNOWLEDGE GREAT } \\
\text { BRITAIN }\end{array}$ \\
\hline 21 & SOCIETY OF FRIENDS ENGLAND \\
\hline 21 & STEELE RICHARD SIR 1672-1729 \\
\hline 21 & SUBLIME THE \\
\hline 21 & SUGAR TRADE GREAT BRITAIN \\
\hline 21 & TITHES \\
\hline \multicolumn{2}{|c|}{ Group III: A selection of relatively infrequently applied subject headings } \\
\hline 5 & ABELARD PETER 1079-1142 CORRESPONDENCE \\
\hline 5 & ABSENTEE LANDLORDISM \\
\hline 5 & ACHILLES GREEK MYTHOLOGY POETRY \\
\hline 5 & ACTORS GREAT BRITAIN BIOGRAPHY \\
\hline 5 & ACTRESSES CORRESPONDENCE REMINISCENCES ETC \\
\hline
\end{tabular}




\begin{tabular}{|c|c|}
\hline \multicolumn{2}{|r|}{$\begin{array}{c}\text { APPENDIX } \\
\text { Selections from the Subject Headings List }\end{array}$} \\
\hline 5 & ADAMS JOHN 1735-1826 \\
\hline 5 & ADAMS WILLIAM 1706-1789 TEST OF TRUE AND FALSE DOCTRINES \\
\hline 5 & AGIS II KING OF SPARTA DRAMA \\
\hline 5 & AGRICULTURE ECONOMIC ASPECTS GREAT BRITAIN \\
\hline 5 & AGRICULTURE WALES \\
\hline 5 & AGRICULTURE WALES NORTH \\
\hline 5 & AIR EARLY WORKS TO 1800 \\
\hline 5 & ALCOHOLISM GREAT BRITAIN \\
\hline 5 & ALFRED KING OF ENGLAND 849-899 DRAMA \\
\hline 5 & ALIENS GREAT BRITAIN \\
\hline 5 & AMHURST N NICHOLAS 1697-1742 \\
\hline 5 & ANALOGY RELIGION \\
\hline 5 & ANGLICAN COMMUNION ENGLAND SERMONS \\
\hline 5 & ANIMAL BEHAVIOR \\
\hline \multicolumn{2}{|c|}{ Group IV: A selection of unique subject headings } \\
\hline 1 & MATHEMATICS TO 1800 \\
\hline 1 & MATHEMATICS UNITED STATES EARLY WORKS TO 1800 \\
\hline 1 & $\begin{array}{l}\text { MATHER ALEXANDER 1733-1800 DEFENCE OF THE CONDUCT OF } \\
\text { THE CONFERENCE IN THE EXPULSION OF ALEXANDER KILHAM }\end{array}$ \\
\hline 1 & $\begin{array}{l}\text { MATHER ALEXANDER APPEAL WITH A WORD OF ADVICE TO THE } \\
\text { METHODIST SOCIETIES }\end{array}$ \\
\hline 1 & MATHER COTTON 1663-1728 BIBLIOGRAPHY \\
\hline 1 & MATHER COTTON 1663-1728 MAGNALIA CHRISTI AMERICANA \\
\hline 1 & $\begin{array}{l}\text { MATHER INCREASE 1639-1723 BRIEF DISCOURSE CONCERNING THE } \\
\text { UNLAWFULNESS OF THE COMMON PRAYER WORSHIP }\end{array}$ \\
\hline 1 & MATHER NATHANAEL 1631-1697 \\
\hline 1 & MATHER SAMUEL 1626-1671 \\
\hline 1 & $\begin{array}{l}\text { MATHER SAMUEL 1706-1785 ALL MEN WILL NOT BE SAVED FOR- } \\
\text { EVER }\end{array}$ \\
\hline 1 & MATHEWS RICHARD 1676-1751 \\
\hline 1 & $\begin{array}{l}\text { MATHEWS THOMAS } 1676-1751 \text { ACCOUNT OF WHAT PASSD IN THE } \\
\text { ENGAGEMENTS NEAR TOULON }\end{array}$ \\
\hline 1 & $\begin{array}{l}\text { MATHEWS THOMAS 1676-1751 ADMIRAL MATHEWSS REMARKS ON } \\
\text { THE EVIDENCE GIVEN AND THE PROCEEDINGS HAD ON HIS TRIAL }\end{array}$ \\
\hline 1 & $\begin{array}{l}\text { MATHIAS THOMAS JAMES 1754-1835 SHADE OF ALEXANDER POPE } \\
\text { ON THE BANKS OF THE THAMES }\end{array}$ \\
\hline 1 & MATHIAS THOMAS JAMES 1754-1835 THE PURSUITS OF LITERATURE \\
\hline 1 & MATTER EARLY WORKS TO 1800 \\
\hline
\end{tabular}


Subject Headings in Full-Text Environments: The ECCO Experiment 81

\begin{tabular}{|l|l|}
\hline \multicolumn{1}{|c|}{ APPENDIX } \\
\multicolumn{1}{|c|}{ Selections from the Subject Headings List } \\
\hline \hline 1 & MATTER PROPERTIES EARLY WORKS TO 1800 \\
\hline 1 & MATTIOLI ERCOLE ANTONIO CONTE 1640-1703 \\
\hline 1 & MATY MATTHEW 1718-1776 \\
\hline 1 & MAUBERT DE GOUVEST JEAN HENRI 1721-1767 \\
\hline 1 & $\begin{array}{l}\text { MAUDIT ISRAEL 1708-1767 CONSIDERATIONS ON THE PRESENT } \\
\text { GERMAN WAR }\end{array}$ \\
\hline 1 & $\begin{array}{l}\text { MAUDUIT ISRAEL 1708-1787 OCCASIONAL THOUGHTS ON THE } \\
\text { PRESENT GERMAN WAR }\end{array}$ \\
\hline 1 & MAUPEOU RENE NICOLAS CHARLES AUGUSTIN DE 1714-1792 \\
\hline 1 & MAUPERTUIS 1698-1759 \\
\hline 1 & MAWSON MATTHAIS 1683-1770 \\
\hline
\end{tabular}

